Article

\title{
Mobile Technologies and the Incidence of Cyberbullying in Seven European Countries: Findings from Net Children Go Mobile
}

\section{Brian O'Neill * and Thuy Dinh}

Centre for Social and Educational Research, Dublin Institute of Technology, Grangegorman, Dublin 7, Ireland; E-Mail: thuy.dinh@dit.ie

* Author to whom correspondence should be addressed; E-Mail: brian.oneill@dit.ie; Tel.: +353-01-402-3481.

Academic Editors: Conor Mc Guckin and Lucie Corcoran

Received: 22 February 2015 / Accepted: 15 April 2015 / Published: 27 April 2015

\begin{abstract}
The harmful effects of bullying and harassment on children have long been of concern to parents, educators, and policy makers. The online world presents a new environment in which vulnerable children can be victimized and a space where perpetrators find new ways to perform acts of harassment. While online bullying is often considered to be an extension of persistent offline behavior, according to EU Kids Online (2011), the most common form of bullying is in person, face-to-face. With the rise in use of mobile Internet technologies, this balance is changing. Increased levels of use and more time spent online accessed through a variety of devices has increased children's exposure to a range of online risks, including cyberbullying. This article presents the findings of the Net Children Go Mobile project, a cross-national study of children aged 9-16 in seven European countries. The research builds on the work of EU Kids Online and supports the identification of new trends in children's online experiences of risk and safety. The study finds that while overall levels of bullying have remained relatively static, levels of online bullying have increased, particularly among younger teens. The relationship between cyberbullying and the use of mobile Internet technologies is examined and factors contributing to increased levels of cyberbullying are highlighted.
\end{abstract}

Keywords: Net Children Go Mobile; cyberbullying; Internet safety; coping and resilience 


\section{Introduction}

The rapidity with which the Internet has been embraced by young people and the speed at which it has impacted on the environment for young people's informational, educational, and entertainment needs is remarkable. Young people have been at the fore in embracing new Internet technologies [1], adapting them effortlessly to new modes of social interaction [2] and forging new and often unexpected opportunities for learning [3]. Yet, a dual discourse counterpointing the diverse opportunities that the Internet affords with attendant risks and concerns with how best to manage young people's engagement with a complex amalgam of technologically-mediated content and contact risks has preoccupied policy makers, almost since its inception [4].

The harmful effects of bullying and harassment on children have long been of concern to parents, educators, and policy makers, long before the Internet became such a feature of contemporary life. That the online world presents a new environment in which vulnerable children can be victimized and a space where perpetrators find new ways to perform acts of harassment has been acknowledged by educators and online safety aspects as one of the main challenges facing children's online participation. Yet, the extent to which use of the Internet by young people has contributed to experiences of being bullied remains a challenging research question. Multinational studies such as EU Kids Online and Net Children Go Mobile have sought to enhance knowledge of European children's online opportunities, risks, and safety through the development of a robust evidence base towards understanding the online landscape that increasingly frames children and young people's experience. Children's accounts of risks and harm experienced through their use of the Internet provide the basis for the current study with a particular focus on the use of mobile Internet technologies such as smartphones, tablets, and other mobile connected devices. The study draws on children's responses from seven participating European countries and provides a baseline on which to assess trends in the situations that children find problematic. Bullying and online harassment feature as one of the risks asked about and while not the most prevalent of "risky" experiences that children describe, it is the one that was found to have the most severe impact.

\section{Researching Young People's Internet Use}

In response to growing policy concerns regarding online safety for children as well as a lack of reliable evidence in Europe, researchers have sought to develop better knowledge of European children's experiences and practices regarding risky and safer use of the Internet and new online technologies, and thereby to inform the promotion of a safer online environment for children. EU Kids Online has been one of the most prominent contributors in this regard. Beginning in 2006, EU Kids Online, with the support of the European Commission's (EC) Safer Internet Program, has in three successive phases of work sought to enhance knowledge of children's experiences and practices regarding risks and safety on the Internet. It has been acknowledged as the primary source in Europe of high-quality, independent, and comprehensive evidence underpinning a better and safer Internet for children in Europe [5].

The aim of the Net Children Go Mobile project, which followed EU Kids Online, is to study children's and young people's use of mobile Internet technologies and to examine consequences they may have for children's online well-being. Employing both quantitative and qualitative methodologies, 
the research focuses specifically on how new mobile conditions of Internet access and use (smartphones, tablets, other portable devices and use of Wi-Fi) bring greater or lesser risks to children's online safety. Given the rapid adoption of convergent mobile media and the changes associated with mobile Internet access at home, in school, and when out and about, mobile media technologies provide children with potential new opportunities, while at the same time exposing them to new risks.

The proliferation of mobile connected devices has greatly expanded children's and young people's opportunities to go online and access the Internet outside the confines of the home. Research has shown that the social context of Internet access and use is a major factor in shaping children's online experiences [6]. With mobile, "always-on" connectivity, the locations, time spent, and ways of using the Internet are likely to intensify, creating new challenges for parents, educators, and policy makers [7].

\section{Theoretical Framework}

Previous research $[6,8,9]$ indicates that the patterns and social contexts of general Internet use are key factors shaping children's online activities and online risks encountered. Online experience is defined as a pathway composed of the online activities engaged in by children and the online and offline factors (family, social ecological environment, etc.) that shape children's behaviors toward the technological world. This approach, based on Bronfenbrenner's work [10], offers a re-conceptualization of the child's ecology as a multi-layered set of nested and interconnecting environmental systems, all of which influence the developing child but with varying degrees of directness. The perspective has evolved since its early inception and today acknowledges the role of the child's own characteristics, hence the model is now referred to as the bio-ecological model [10]. The framework recognizes the complex interdependencies between the institutions and structures that support or constrain children's opportunities and their agency in making choices and decisions online while negotiating these possibilities and constraints [11].

Children's Internet use may be investigated on two levels [6]. The most common way is to consider the child as the unit of analysis, examining both individual (demographic, psychological) factors and factors relating to their social environment (parents, peers, and teachers). This allows the analysis of the process and consequences of online activities contextualized within the "meso" and "macro" system of children's lives [11]. Parents are the most influential part of the ecology, as are, for example, school and childcare arrangements. As these have the most direct contact with the child, they are represented in the circle or layer immediately surrounding the individual (the microsystem).

This analysis builds on our previous work [12] exploring a child-centered approach to children's experiences, perspectives, and action in relation of the use of the Internet, contextualizing them within concentric circles of structuring social influences - family, community, and culture [6]. By using the bio-ecological approach in which media are no longer investigated in their individual textuality or as a cluster of isolated material practices, but rather as "an overall technical social, cultural and place-based system, in which components are not decomposable or separable" [13].

Another plausible framework is the usage paradigm, which connects Internet use with online opportunities and risk [14,15]. This approach, characterized by the underlying rule "the more opportunities, the more risks" [8,16] implies that the more children use the Internet, the more they learn to reap its benefits and deal in healthy and non-harmful ways with potential risk. However, risk does not always result in harm; and risk taking can be beneficial in terms of building resilience [6]. 


\section{Incidence of Bullying in Seven European Countries}

Bullying was one of four types of online risk asked about in the Net Children Go Mobile survey. Young people were asked if they had themselves experienced bullying either online or offline; what impact this had on them; and what actions they took in attempting to deal with the problem, for example, who they spoke to or what action they took to deal with the problem.

Despite being a recurrent theme in research and in public and policy debates, there is no standard definition of "cyberbullying." Bullying has been defined as a form of aggression that is (a) intentional; (b) repetitive; and (c) involves a power imbalance between a victim and a perpetrator [17]. Accordingly, cyberbullying is defined as intentional and repeated aggression using any form of technological device such as the Internet or mobile phone.

To avoid adopting contested, adult, or emotionally-charged terms, bullying was defined in the Net Children Go Mobile study as follows: Sometimes children or teenagers say or do hurtful or nasty things to someone and this can often be quite a few times on different days over a period of time, for example. This can include: teasing someone in a way this person does not like; hitting, kicking or pushing someone around; intentionally leaving someone out of things. When people are hurtful or nasty to someone in this way, it can happen: in person face to face (a person who is together with you in the same place at the same time); by mobile phone (texts, calls, video clips); on the Internet (email, instant messaging, social networking, chatrooms); on whatever device you use to go online.

\subsection{Survey Sample and Procedure}

The main data used in this article is taken from the Net Children Go Mobile (NCGM) survey. A total of 3500 children who use the Internet were interviewed during winter 2013 and spring 2014, across seven European countries (UK, Denmark, Italy, Romania, Ireland, Portugal, and Belgium) [18]. Many of the questions asked in this survey replicate precisely those asked in the EU Kids Online survey conducted in 25 European countries in 2010 [8].

The NCGM survey involved a random stratified sample of around 500 children aged 9-16, who are Internet users, per country. The sampling frame started with a known population base taken from national registers, that is, the general population in most countries and the population of children aged 9-16 years in some others. Using official registers of geographical units, country regions were stratified to ensure that smaller geographical and rural areas were included. From each stratum (that is, those identified in the stratification process), random sampling points were selected with a selection probability proportionate to the number of children aged 9-16 living in the area. Different address selection methods imply different degrees of sample representativeness. The interview was conducted in children's homes, as a face-to-face interview. It included a self-completion section for sensitive questions. Average interview time per child was 40 min [18]. To ensure children's comprehension, the wording of these questionnaires was refined on the basis of cognitive testing with children of different age groups $(9-10,11-12,13-14,15-16)$ and gender in each country. The Net Children Go Mobile survey continued to use EU Kids Online's conceptual framework, which is operationalized in a child-centered, critical, contextual, and comparative approach [8].

For the purpose of comparison, the trends and patterns of cyberbullying incidences, between two periods of time (2010 and 2014) were identified. On several occasions we compared the findings of the 
Net Children Go Mobile survey with the 2010 EU Kids Online survey. When such comparisons are made we calculated an average number from the EU Kids Online survey only for the countries included in the Net Children Go Mobile survey, thus attempting to provide as direct a comparison as possible.

When direct comparisons are made to the EU Kids Online survey, the data are presented as "EUKO 2010" whereas the Net Children Go Mobile data are presented as "NCGM 2014."

\subsection{Incidence of Bullying, Offline and Online}

Table 1 presents the findings in response to the question of whether the child had been bullied online or offline in the past 12 months and whether this was an experience that had upset them. Prior research has shown that, while cyberbullying is less common than offline bullying [8], it is a very distressing and harmful experience [8]. Online bullying is often understood as an extension of persistent offline behavior. The shift from offline to online spaces means that the boundaries of space and time are becoming non-existent: one cannot leave a place and know that the bullying will end; rather, the bullying is likely to take place not only at the school yard but also after school, on a variety of platforms. Research has also shown that compared to face-to-face forms of bullying, the boundaries between the roles of victim, perpetrator, and bystanders are less easily drawn in online bullying [19].

Table 1. Child has been bullied online or offline in the past 12 months (\%).

\begin{tabular}{|c|c|c|c|c|}
\hline & Has not been bullied & $\begin{array}{l}\text { Victim of bullying } \\
\text { but not upset }\end{array}$ & $\begin{array}{c}\text { Victim and } \\
\text { a little } \\
\text { upset }\end{array}$ & $\begin{array}{l}\text { Victim and } \\
\text { very upset }\end{array}$ \\
\hline Row percentages & 77 & 6 & 12 & 5 \\
\hline \multicolumn{5}{|l|}{ Age } \\
\hline $9-10$ & 76 & 3 & 14 & 7 \\
\hline $11-12$ & 81 & 5 & 10 & 4 \\
\hline $13-14$ & 74 & 7 & 15 & 4 \\
\hline $15-16$ & 78 & 9 & 8 & 5 \\
\hline \multicolumn{5}{|l|}{ Gender } \\
\hline Male & 81 & 6 & 10 & 3 \\
\hline Female & 74 & 6 & 14 & 6 \\
\hline \multicolumn{5}{|l|}{$S E S$} \\
\hline Low & 80 & 5 & 10 & 5 \\
\hline Medium & 73 & 8 & 14 & 5 \\
\hline High & 79 & 5 & 12 & 4 \\
\hline \multicolumn{5}{|l|}{ Country } \\
\hline Belgium & 87 & 5 & 7 & 1 \\
\hline Denmark & 61 & 11 & 20 & 8 \\
\hline Ireland & 78 & 6 & 10 & 6 \\
\hline Italy & 87 & 5 & 7 & 1 \\
\hline Portugal & 90 & 4 & 4 & 2 \\
\hline Romania & 59 & 8 & 22 & 11 \\
\hline UK & 79 & 3 & 12 & 6 \\
\hline
\end{tabular}

Base: All children aged between 9 and 16 who use the Internet, NCGM 2014. 
According to Net Children Go Mobile, nearly one in four (23\%) 9-16-year-olds say that they have experienced some form of bullying, online or offline, in the past 12 months. For $6 \%$ of children, this was not an upsetting experience. However, the majority of children who have experienced bullying find it upsetting. Seventeen percent of children overall said they were "very" (5\%) or "a little upset" $(12 \%)$ about what happened. It is, however, the youngest children who report higher rates of being upset by being bullied (21\%).

Gender differences are marked. The incidence of bullying is higher among girls overall and for those in their mid-teens, aged 13-14 years (26\%). Girls are more likely to experience bullying (26\%) than boys (19\%) and more likely to be upset (20\%) compared to $13 \%$ of boys.

Only slight differences by socioeconomic status are noted with children from middle SES homes reporting more frequent levels of bullying.

It is at the country level where the greatest differences in incidence of bullying are to be found. The average of $23 \%$ of $9-16$-year-old children experiencing some form of bullying incorporates therefore a wide variation from high levels of bullying experienced in Romania (41\%) and Denmark (39\%) to much lower levels in Portugal (10\%), Belgium, and Italy (both 13\%). The UK and Ireland (21\% and $22 \%$, respectively) are the only two countries that lie close to the average of the seven countries in the NCGM survey.

Figure 1 compares the 2010 and 2014 findings by age and gender for bullying overall and for cyberbullying.

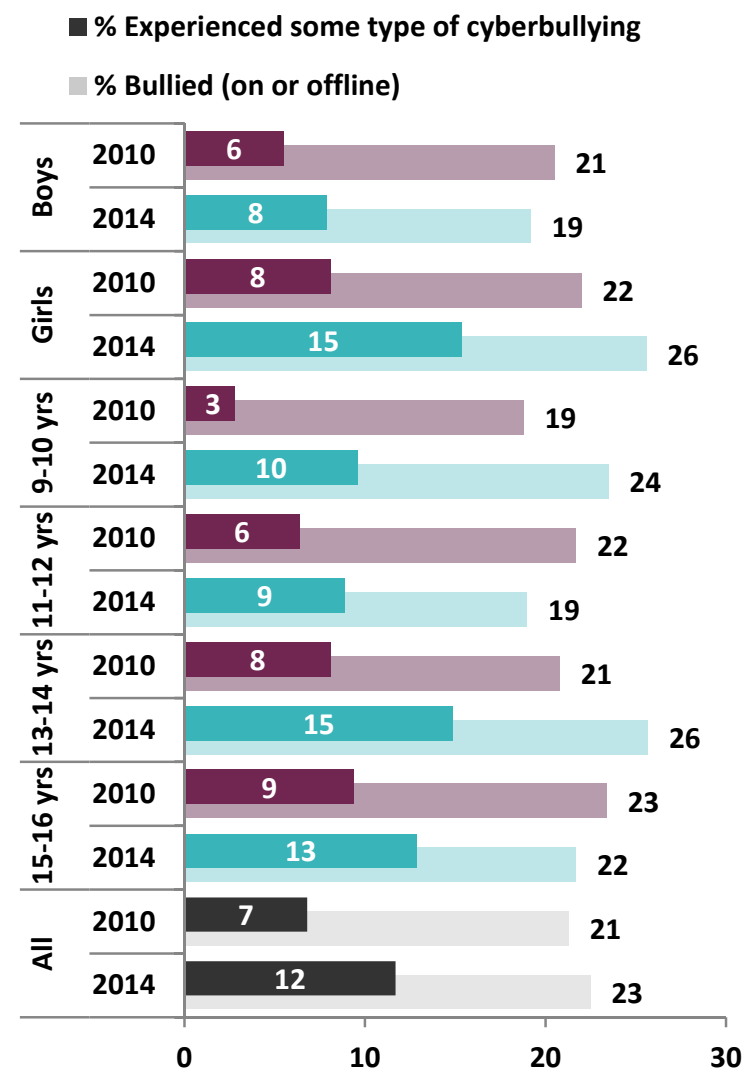

Figure 1. Being bullied off/online, by gender and age, comparing EUKO 2010 and 2014 NCGM 2014. Base: All children aged who use the Internet. 
A comparison of the EUKO 2010 and NCGM 2014 findings reveals that offline bullying is no longer the dominant form of bullying experienced by young people. Overall levels of bullying have risen marginally from $21 \%$ to $23 \%$. However, the number of children who report being bullied online or through any form on the Internet or mobile phones has nearly doubled from $7 \%$ to $12 \%$ in the period from 2011 to 2014. An increase in bullying among girls, and a slight decline among boys, is noteworthy. This is especially the case in relation to girls' reports of cyberbullying, where almost a doubling of online bullying from $8 \%$ to $15 \%$ is reported.

Age variations are also significant. There are increased reports of bullying among young children, 9-10 years of age, and among 13-14 year olds. Older teens aged 15-16 as well as 12-13report a slight decline in experiences of being bullied. However, reports of cyberbullying have increased among all groups. The most substantial increase is in fact among younger users, aged 9-10, where reports have trebled from $3 \%$ to $10 \%$ between 2011 and 2014, and doubled among 13-14-year-olds, from $8 \%$ to $15 \%$.

\subsection{What Form Does Cyberbullying Take?}

Bullying can occur in many ways and in the survey children were asked if someone had treated them in a hurtful or nasty way and how this had happened. Children were also asked if they had behaved in this way to someone else. For purposes of comparison, forms of bullying included in the EU Kids Online survey were listed in addition to new forms of mobile media use. Table 2 presents the ways in which children have been bullied by age and gender.

Table 2. Ways in which children have been bullied/bullied others in the past 12 months, by age and gender $(\%)$.

\begin{tabular}{|c|c|c|c|c|c|c|c|c|c|c|}
\hline & \multicolumn{5}{|c|}{$\begin{array}{c}\text { Ways in Which Children } \\
\text { Have been Bullied }\end{array}$} & \multicolumn{5}{|c|}{$\begin{array}{c}\text { Ways in Which Children } \\
\text { Have Bullied Others }\end{array}$} \\
\hline & \multicolumn{2}{|c|}{ 9-12 } & \multicolumn{2}{|c|}{$13-16$} & \multirow{2}{*}{ All } & \multicolumn{2}{|c|}{$9-12$} & \multicolumn{2}{|c|}{$13-16$} & \multirow{2}{*}{ All } \\
\hline & Girls & Boys & Girls & Boys & & Girls & Boys & Girls & Boys & \\
\hline In person/face-to-face & 9 & 12 & 10 & 11 & 10 & 8 & 9 & 8 & 8 & 8 \\
\hline By mobile phone calls & 1 & 1 & 1 & 2 & 2 & 2 & 2 & 3 & 1 & 2 \\
\hline $\begin{array}{l}\text { By messages sent to me on my } \\
\text { phone (SMS, text, or MMS) }\end{array}$ & 2 & 2 & 6 & 2 & 3 & 2 & 2 & 4 & 2 & 3 \\
\hline On a social networking site & 4 & 3 & 14 & 5 & 7 & 2 & 1 & 3 & 4 & 3 \\
\hline On a media sharing platform & 0 & 0 & 2 & 1 & 1 & 0 & 1 & 1 & 1 & 1 \\
\hline By instant messaging & 1 & 2 & 2 & 1 & 2 & 1 & 1 & 1 & 1 & 1 \\
\hline In a chatroom & 1 & 1 & 1 & 0 & 1 & 0 & 1 & 1 & 1 & 1 \\
\hline By email & & & & & 0 & & & & & 0 \\
\hline On a gaming website & 3 & 2 & 1 & 1 & 2 & 2 & 1 & 1 & 2 & 2 \\
\hline Other & 1 & 0 & 1 & 1 & 1 & 1 & 1 & 1 & 1 & 1 \\
\hline $\begin{array}{l}\text { In any form on the Internet } \\
\text { or through mobile phones }\end{array}$ & 10 & 8 & 20 & 8 & 12 & 8 & 7 & 8 & 8 & 8 \\
\hline
\end{tabular}

Base: All children who use the Internet, NCGM 2014.

While $10 \%$ of children have been bullied face-to-face, offline bullying, as noted above, is no longer the dominant mode of bullying behavior. In fact, $12 \%$ of children report being bullied through some 
technologically mediated form, online, or through mobile communication. The most common forms of cyberbullying reported is via a social networking site (SNS) at 7\%. SMS messages and texts sent to the child's phone account for 3\%, while phone calls, instant messaging, and gaming websites are each reported by $2 \%$ of children. Email, media sharing platforms, and chatrooms do not appear to be significant threats for online bullying.

Age differences are noteworthy. The youngest children are more likely to report being bullied face-to-face and on a gaming website. By contrast, teenagers are more likely to experience cyberbullying on social networking sites. Teenagers also report more experiences of cyberbullying via SMS and phone calls.

The gender differences in reports of being bullied are particularly significant. While bullying face-to-face is something of a constant across the age groups, more girls report being bullied at all, with gender being a factor in the different forms that cyberbullying takes. Overall, slightly more boys than girls reported being bullied face-to-face, especially in the younger age group. However, among teenagers, more than twice as many girls report being bullied online than boys ( $20 \%$ compared to $8 \%$ ). Gender differences are marked in each of the dominant forms of cyberbullying: three times as many girls than boys report being bullied by SMS (6\% vs. 2\%), and girls report more than twice the amount of bullying on social networking sites (14\% vs. 5\%).

When it comes to children's accounts of bullying others, there are equal reports of bullying face-to-face as well as online bullying. Eight percent of young people report having bullied others either online or offline in the past 12 months. Younger boys are slightly more likely to have bullied others. Notably, while 13-14-year-old girls report the highest levels of being bullied on a social networking site (14\%), just 3\% say they have bullied others this way.

\subsection{Prevalence of Cyberbullying on SNS and Mobile Platforms}

The role of social networking sites is of particular interest. Social networking remains one of the most popular activities for young people online, with SNS being one of the most important venues for young people connecting, communicating, and socializing with peers, as well as identity building and self-expression [20]. EU Kids Online found in 2010 that over one-third of 9-12-year-olds and three-quarters of 13-16-year-olds who use the Internet in Europe have their own profile on a social networking site (SNS) [9]. Net Children Go Mobile reports a slight decline in this finding with 68\% of children overall having at least one profile on a social networking site [21]. This is largely attributed to the decline in underage social networking use for 9-12-year-olds. Among teenagers $84 \%$ of 12-14-year-olds and 93\% of 15-16-year-olds report having an SNS profile.

The role that social networking plays in experiences of cyberbullying, particularly for girls and younger children, is illustrated in Figure 2. The data shows that children, both boys and girls across all age groups, who have at least one SNS profile, are at least twice as likely to be cyberbullied as children who have no SNS profile. In particularly, 22\% of 13-16-year-old girls who have at least one SNS profile are more likely to be cyberbullied, compared to $4 \%$ of girls from the same age group. Similarly, $9 \%$ of 13-16-year-old boys who have at least one SNS profile are more likely to be bullied compared to $1 \%$ of boys from the same age group. Again, gender and age differences are notable with girls and younger children (both with or without a SNS profile) are more likely to be cyberbullied. 


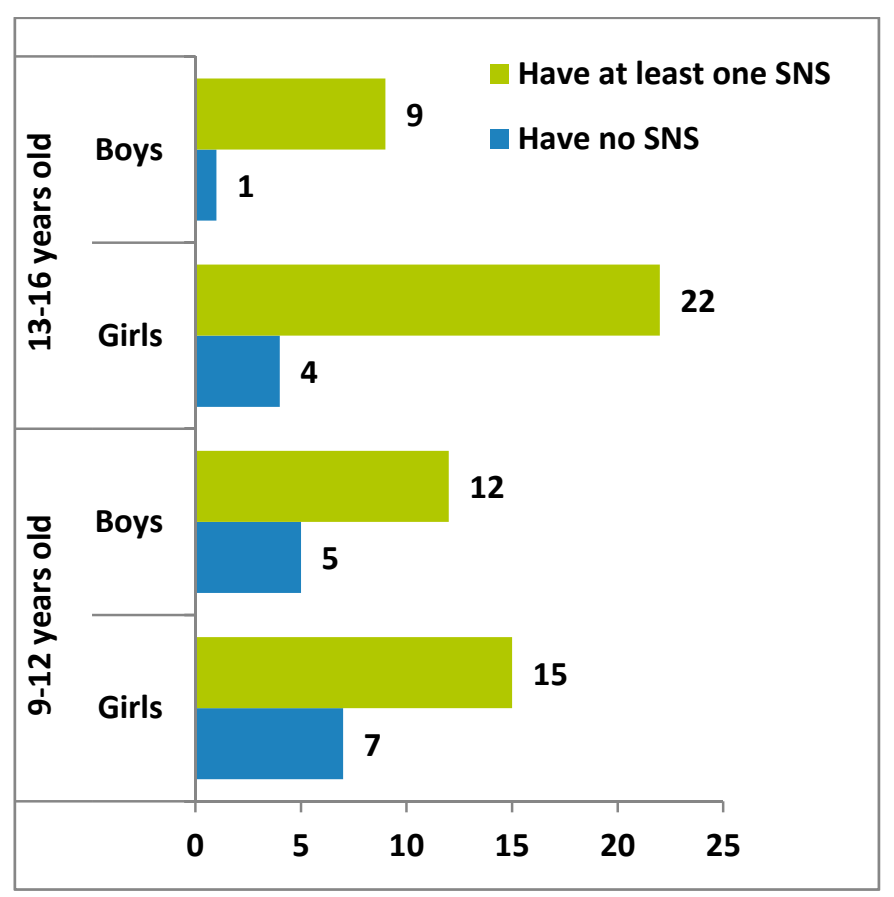

Figure 2. Children being cyberbullied, with or without SNS (\%) by age and gender. Base: All children who use the Internet, NCGM 2014.

Yet, the pervasiveness of social networking among teenagers is just one factor in experiences of cyberbullying. The use of mobile technologies, one of the primary areas of interest for the Net Children Go Mobile study, also features strongly in young people's reports of cyberbullying. Table 3 shows that smartphone users (17\%) and tablet users (15\%) are more likely to have experienced any form of cyberbullying than children who do not use mobile devices at all (8\%). Smartphone users are also more likely to have engaged in any form of cyberbullying. There are no differences among the different categories of Internet users in the likelihood of being bullied face-to-face and there is only a marginal difference in the likelihood of bullying others face-to-face.

Table 3. Ways in which children have been bullied in the past 12 months, comparing mobile and non-mobile Internet users (\%).

\begin{tabular}{cccc}
\hline & $\begin{array}{c}\text { Among } \\
\text { Smartphone Users }\end{array}$ & $\begin{array}{c}\text { Among Tablet } \\
\text { Users }\end{array}$ & Use Neither \\
\hline Have experienced any form of cyberbullying & 17 & 15 & 8 \\
Been bullied in person, face-to-face & 10 & 10 & 10 \\
Have engaged in any form of cyberbullying & 9 & 6 & 8 \\
Have bullied others in person, face-to-face & 8 & 9 & 8 \\
\hline
\end{tabular}

Base: All children who use the Internet, NCGM 2014.

\section{How Do Children Cope?}

Building resilience and enabling young people to cope with online problems that may bother or upset them is an important objective of online safety education. Children try a range of coping strategies, when faced with upsetting experiences online. These include individual coping strategies such as trying to deal with the problem themselves; social coping strategies, which include seeking 
help from others; as well as technical solutions, such as blocking the sender or reporting the abuse using an online reporting tool.

According to EU Kids Online, the most common individual coping strategy for experiences of being bullied online was a proactive one whereby the child tried to solve the problem on his/her own (31\%). This was followed by the more fatalistic strategy in that a quarter of children who had been bullied hoped the problem would go away by itself (24\%) [8]. Net Children Go Mobile focused on social coping strategies and the forms of social support that children sought in the context of experiencing bullying. Findings from EU Kids Online have shown that most children who had been bullied (four in five or $77 \%$ ) talked to somebody about it.

\subsection{Seeking Social Support for Upsetting Experiences Online}

In the Net Children Go Mobile project, children were asked: if they were to experience something on the Internet or when they were online that bothered them or made them upset, how likely or unlikely is it that they would talk to a parent, a sibling, friends, or others (Table 4).

Table 4. Who children are likely to talk about things that bothered them on the Internet, by age and gender.

\begin{tabular}{cccccc}
\hline $\begin{array}{c}\text { Who Children Are Likely to Talk to } \\
\text { When Something Bothers Them ... (\%) }\end{array}$ & \multicolumn{2}{c}{$\mathbf{9 - 1 2}$ Years } & \multicolumn{2}{c}{$\mathbf{1 3 - 1 6}$ Years } & \multirow{2}{*}{ All } \\
\hline \% very likely ... & Boys & Girls & Boys & Girls & \\
My father & 43 & 39 & 29 & 23 & 33 \\
My mother & 52 & 65 & 32 & 44 & 48 \\
My brother or sister & 20 & 22 & 13 & 26 & 20 \\
Other relatives & 9 & 10 & 7 & 8 & 8 \\
Friends & 17 & 16 & 27 & 42 & 26 \\
Teachers & 10 & 8 & 4 & 7 & 7 \\
Another adult I trust & 7 & 8 & 6 & 7 & 7 \\
Someone whose job is to help children & 8 & 8 & 8 & 7 & 8 \\
\hline
\end{tabular}

Base: All children who use the Internet, NCGM 2014.

Parents, both mothers and fathers, remain the primary source of social support in cases of experiencing something upsetting on the Internet. As shown in Table 4, younger children are more likely to talk to their parents than anyone else, with both girls and boys most likely to seek support from mothers (65\% and 52\%, respectively). However, parental support decreases with age. While teenagers are still most likely to seek support from a parent (and in this case mothers are the most likely source of social support), teenagers also turn in significant numbers to seek support from their peers.

Gender is a significant factor here. While older girls are more likely to talk with their friends (42\%) and still more likely to turn to their mothers (44\%), teenage boys continue to seek support from parents (29\% for father and $32 \%$ for mother) more than friends (27\%).

The importance of peer support in dealing with upsetting experiences of bullying is well established [22]. This survey finds that after parents, peers are the next most important form of social support. This is particularly noteworthy in the case of teenage girls, $42 \%$ of whom say they would turn 
to a friend about something that had upset them online. It is interesting to note also that siblings likewise offer an important form of social support: one in five of all children, a quarter of teenage girls, say that they would turn to a sibling if they were upset about something online.

Overall, children do not turn to teachers in any significant numbers. Given the importance of schools in reinforcing positive messages about online safety and in promoting effective strategies to deal with bullying, this low finding is perhaps surprising. Just $7 \%$ of children mention a teacher as a likely source of support, though younger children are somewhat more likely to talk to a teacher.

Table 5 shows that country variations are also pronounced here, with Portuguese and Belgian children more likely to look for social support ( $80 \%$ and $78 \%$, respectively). By contrast, children in Denmark are the least likely to do so (56\%). Mothers are the main source of support for children in all countries, especially in Portugal, Belgium, and the UK. In most countries, children are likely to talk to their mothers or fathers when something bothers them on the Internet, except Romania, where children choose their brother or sister or friends (25\% and $24 \%$, respectively) over their fathers (19\%). In most countries, the percentages of children who talk to teachers when something bothers them are relatively low, varying from 4 to 7 percent, with the exception of Portuguese children (30\%). However, overall, one in three children is still unlikely to ask for support from parents, peers, or teachers.

Table 5. Who children are likely to talk about things that bothered them on the Internet, by country $(\%)$.

\begin{tabular}{|c|c|c|c|c|c|c|c|c|}
\hline $\begin{array}{c}\text { Who Children Are } \\
\text { Likely to Talk to } \\
\text { When Something } \\
\text { Bothers Them ... (\%) }\end{array}$ & UK & RO & PT & IT & IE & DK & BE & All \\
\hline \multicolumn{9}{|l|}{ \%..very likely } \\
\hline My father & 35 & 19 & 53 & 23 & 31 & 24 & 45 & 33 \\
\hline My mother & 50 & 36 & 68 & 40 & 45 & 33 & 62 & 48 \\
\hline My brother or sister & 15 & 25 & 35 & 17 & 16 & 13 & 22 & 20 \\
\hline Other relatives & 7 & 10 & 15 & 2 & 10 & 2 & 13 & 8 \\
\hline Friends & 24 & 24 & 32 & 29 & 24 & 26 & 24 & 26 \\
\hline Teachers & 6 & 6 & 20 & 3 & 7 & 4 & 5 & 7 \\
\hline $\begin{array}{l}\text { Someone whose job is } \\
\text { to help children }\end{array}$ & 5 & 4 & 13 & 2 & 7 & 9 & 8 & 7 \\
\hline Another adult I trust & 7 & 8 & 9 & 5 & 13 & 5 & 8 & 8 \\
\hline $\begin{array}{l}\text { At least one of the } \\
\text { above }\end{array}$ & 64 & 63 & 80 & 63 & 65 & 56 & 78 & 67 \\
\hline
\end{tabular}

Base: All children who use the Internet, NCGM 2014.

\subsection{Past Experiences of Social Support}

Most children (67\%) say that they would talk to someone if something had bothered them online. But what about their previous experiences: have children in fact received support from parents, friends, or teachers in the past when something upset them on the Internet? Similarly, have parents, teachers, or friends spoken to them about what they would do if something ever bothered them online? Table 6 examines past experiences of having received social support from one of these sources. 
Table 6 shows that parents are both the most important sources of mediation of online safety and the source of social support when something upsetting happened in the past. Fifty-seven percent of parents have spoken to their children about how to handle a problematic situation online and $41 \%$ have helped their children in the past with an upsetting experience. The role of parents in giving advice about how to cope is a constant with all age groups and somewhat higher for younger children. With the exception of older teens, parents are also the ones who have helped in specific situations that have occurred.

There is a gendered dimension to parental support. Both in terms of giving advice and actually intervening in situations where the child has been upset, parents are more likely to respond to girls than boys. There are also some interesting differences in SES in relation to parental support. While more parents from lower SES homes have spoken about how to handle an upsetting situation online, a higher proportion of parents from high SES homes have actually helped in a difficult situation that arose.

The role of peer support is one that rises steadily with age. Younger children, especially 9-10 years of age, seek social support primarily from parents. As children get older, peers become more important, equaling the role of parents for older teenagers. This is especially the case for girls, $37 \%$ of whom have been helped by friends when something upset them online.

Table 6. Social support provided by parents, friends, and teachers (\%).

\begin{tabular}{|c|c|c|c|c|c|c|}
\hline \multirow[b]{2}{*}{$\%$} & \multicolumn{3}{|c|}{$\begin{array}{l}\text { Have Helped Children in the Past When } \\
\text { Something Bothered Them on the Internet }\end{array}$} & \multicolumn{3}{|c|}{$\begin{array}{c}\text { Have Talked to You about What You Would Do If } \\
\text { Something on the Internet Ever Bothered You }\end{array}$} \\
\hline & Parents & Friends & Teachers & Parents & Friends & Teachers \\
\hline All & 41 & 32 & 23 & 57 & 33 & 40 \\
\hline \multicolumn{7}{|l|}{ Age } \\
\hline $9-10$ & 42 & 17 & 22 & 58 & 19 & 37 \\
\hline $11-12$ & 43 & 28 & 21 & 60 & 28 & 39 \\
\hline $13-14$ & 42 & 38 & 21 & 55 & 39 & 39 \\
\hline $15-16$ & 36 & 41 & 27 & 56 & 42 & 45 \\
\hline \multicolumn{7}{|l|}{ Gender } \\
\hline Male & 36 & 26 & 21 & 51 & 28 & 36 \\
\hline Female & 45 & 37 & 25 & 63 & 38 & 44 \\
\hline \multicolumn{7}{|l|}{ SES } \\
\hline Low & 36 & 32 & 24 & 65 & 30 & 30 \\
\hline Medium & 39 & 32 & 24 & 60 & 34 & 34 \\
\hline High & 51 & 32 & 24 & 50 & 35 & 35 \\
\hline
\end{tabular}

Base: All children who use the Internet, NCGM 2014.

Despite the fact that just $7 \%$ of children say they would turn to a teacher if something bothered them online, one in five of all 9-16-year-olds have in fact been helped by teachers, rising to $27 \%$ of $15-16$-year-olds. It is also notable that teachers actively engage with children of all ages, from $37 \%$ of 9-10-year-olds to $44 \%$ of 15-16-year-olds, on how to deal with upsetting experiences online. Again, somewhat more girls than boys report having been helped by teachers. 


\section{Conclusions}

The findings presented by the Net Children Go Mobile project show a rise in cyberbullying compared to data revealed by EU Kids Online. EU Kids Online found that while cyberbullying was not the most prevalent risk that young people encounter online, it is the one that has the most severe impact [8]. Its findings showed that cyberbullying is a phenomenon that particularly affects teenagers, is closely associated with more intensive Internet use, and happens mostly on social networking sites [12]. With new data from seven of the original 25 countries, Net Children Go Mobile shows that while overall incidence of bullying has not increased since the EU Kids Online survey, cyberbullying is now more prevalent than face-to-face bullying and occurs most commonly on SNS.

This shift in experiences from bullying offline to online is most noticeable for girls and for early teenagers and is markedly a feature of increased use of mobile media technologies such as smartphones and tablets. More research is needed into the causes and contexts that give rise to bullying behavior. However, it is tempting to view the "always-on" connectivity afforded by portable and personal media as a contributory factor to increased reports of being bullied online. The question of whether this is a direct outcome of new media devices or rather, a result of changing ways in which children access and use the Internet requires further analysis. It is also the case that since the original EU Kids Online survey, extensive educational awareness campaigns have taken place, sensitizing young people to the phenomenon and raising awareness of bullying behavior, the role of bystanders and the blurred lines between being bullied and bullying. More generally, the Net Children Go Mobile project has tended to view the "more opportunities, more risks" hypothesis as a valid framework for understanding the changes associated with smartphones and tablets, changes that lead to more pervasive Internet access and use in children's everyday lives [21].

\section{Acknowledgments}

Funding support from the Department of Education and Skills, Central Policy Unit, and the National Digital Strategy Unit-Department of Communications Energy and Natural Resources-is gratefully acknowledged.

\section{Author Contributions}

Both authors made an equal contribution to this work.

\section{Conflicts of Interest}

The authors declare no conflict of interest.

\section{References and Notes}

1. Rice, R.; Haythornthwaite, C. Handbook of New Media: Social Shaping and Social Consequences; Lievrouw, L., Livingstone, S., Eds.; Sage: London, UK, 2006; pp. 92-113.

2. Boyd, D. Taken Out of Context: American Teen Sociality in Networked Publics; University of California: Berkeley, CA, USA, 2008. 
3. Ito, M.; Horst, H.A.; Bittanti, M.; boyd, d.; Stephenson, B.H.; Lange, P.G.; Pascoe, C.J.; Robinson, L.; Baumer, S.; Cody, R.; et al. Living and Learning with New Media: Summary of Findings from Digital Youth Project; The MIT Press: Cambridge, MA, USA, 2009

4. Attewell, P.; Suazo-Garcia, B.; Battle, J. Computers and Young Children: Social Benefit or Social Problem? Social Forces 2003, 82, 277-296.

5. Kroes, N. Towards a Better Internet for Children? Policy Pillars, Players and Paradoxes; O’Neill, B., Staksrud, E., McLaughlin, S., Eds.; Nordicom/UNESCO Clearinghouse for Children and Media: Goteborg, Germany, 2013.

6. Livingstone, S., Haddon, L., Görzig, A., Eds. Children, Risk and Safety on the Internet: Research and Policy Challenges in Comparative Perspective; Policy Press: Bristol, UK, 2012.

7. Stald, G.; Green, L.; Barbovski, M.; Haddon, L.; Mascheroni, G.; Ságvári, B.; Scifo, B.; Tsaliki, L. Online on the Mobile: Internet Use on Smartphones and Associated Risks among Youth in Europe; EU Kids Online: London, UK, 2014.

8. Livingstone, S.; Haddon, L.; Görzig, A.; Ólafsson, K. Risks and Safety on the Internet: The Perspective of European Children. Full Findings; EU Kids Online: London, UK, 2011.

9. Livingstone, S.; Ólafsson, K.; Staksrud, E. Social Networking, Age and Privacy; EU Kids Online: London, UK, 2011.

10. Bronfenbrenner, U.; Morris, P.A. The Bio-Ecological Model of Human Development. In Handbook of Child Psychology, 6th ed.; Damon, W., Lerner, R.M., Eds.; Theoretical Models of Human Development, John Wiley: New York, NY, USA, 2006; Volume 1, pp. 793-828.

11. Livingstone, S.; Helsper, E. Children, Internet and risk in comparative perspective. J. Child. Media 2013, 7, 1-8,

12. O’Neill, B.; Dinh, T. Cyberbullying among 9-16 Year Olds in Ireland; Digital Childhoods Working Paper Series, No.5; Dublin Institute of Technology, Centre for Social and Educational Research: Dublin, Ireland, 2013.

13. Ito, M.; Baumer, S.; Bittanti, M.; boyd, d.; Cody, R.; Herr, B.; Horst, H.; Lange, P.; Mahendran, D.; Martinez, K.; et al. Hanging Out, Messing Around, and Geeking Out: Kids Living and Learning with New Media; MIT Press: Cambridge, MA, USA, 2009.

14. Livingstone, S.; Haddon, L. EU Kids Online: Final Report; EU Kids Online: London, UK, 2009.

15. De Haan, J. Maximising opportunities and minimizing risks for children online. In Kids Online: Opportunities and Risks for Children; Livingstone, S., Haddon, L., Eds.; The Policy Press: Bristol, UK, 2009.

16. Livingstone, S.; Helsper, E. Balancing opportunities and risks in teenagers@ use of the Internet: the role of offline social-psychological factors in young people's vulnerability to online risks. New Media Soc. 2010, 12, 309-329.

17. Jackson, C.L.; Cohen, R. Childhood victimization: Modeling the relation between classroom victimization, cyber victimization, and psychosocial functioning. Psychol. Pop. Media Cult. 2012, 1, 254-269.

18. Mascheroni, G.; Ólafsson, K. Net Children Go Mobile: Risks and Opportunities, 2nd ed.; Educatt: Milano, Italy, 2014. 
19. Lampert, C.; Donoso, V. Bullying. In Children, Risk and Safety on the Internet: Research and Policy Challenges in Comparative Perspective; Livingstone, S., Haddon, L., Gorzig, A., Eds.; Policy Press: Bristol, UK, 2012; pp. 141-150.

20. Van Dijck, J. Facebook as a Tool for Producing Sociality and Connectivity. Telev. New Media 2012, 13, 160-176.

21. Mascheroni, G.; Cuman, A. Net Children Go Mobile. Final Report; Educatt: Milano, Italy, 2014.

22. Burrell, N.A.; Zirbel, C.S.; Allen, M. Evaluating Peer Mediation Outcomes in Educational Settings: A Meta-Analytic Review. Confl. Resolut. Q. 2003, 21, 7-26.

(C) 2015 by the authors; licensee MDPI, Basel, Switzerland. This article is an open access article distributed under the terms and conditions of the Creative Commons Attribution license (http://creativecommons.org/licenses/by/4.0/). 